\title{
A newly discovered method of reproduction in gorgonian coral
}

\author{
T. A. Walker* and G. D. Bull \\ Department of Marine Biology, James Cook University, Townsville 4811, Australia
}

\begin{abstract}
The unbranched sea-whip Junceella fragilis reproduces vegetatively by autotomy of colony ends. Polyps and coenenchyme tissue are resorbed at a subterminal point where the axial core breaks to release a daughter colony. This is capable of attachment to the substrate at either end which results in colonies having either upward- or downward-facing polyp verrucae. Large colonies have a higher frequency of reproductive autotomy than small colonies although daughter colony length is largely independent of parent colony size. The process of asexual reproduction gives rise to clumps of $J$. fragilis with a density of up to 300 colonies $\mathrm{m}^{-2}$ at sites along the Great Barrier Reef.
\end{abstract}

\section{INTRODUCTION}

Coral reef animals often reproduce by asexual means (Grassle, 1973; Bell, 1981). Asexual reproduction is considered here to refer to an increase in the number of individual animals or colonies but to exclude the case of enlargement of a colony by increase in the number of zooids. Within the Anthozoa, asexual reproduction is common in the subclass Hexacorallia but it has only recently been described for some members of the subclass Octocorallia. Reproduction by parthenogenesis, pedal laceration, longitudinal fission and budding of solitary polyps is widespread in the Actinaria (Bell, 1981) while colony fragmentation is highly developed in the major reef-building Scleractinia (Highsmith, 1982). Other methods of asexual reproduction in the Scleractinia include transverse fission of polyps or buds in the solitary Fungiidae (Wells, 1966) and release of small daughter colonies from the surface of Goniopora stokesi (Scheer, 1959; Sheppard, 1981). Individual polyps may also detach from scleractinian corals kept in adverse aquarium conditions, and Sammarco (1982) has suggested that this is a method of asexual reproduction in the natural environment. In the Antipatharia, the precious coral Antipathes dichotoma is reported to undergo natural fragmentation

\footnotetext{
- Present address: Marine Parks Section, Queensland National Parks and Wildlife Service, P.O. Box 1362, Rockhampton 4700, Australia
}

of branch ends (Grigg, 1976). Within the Octocorallia, the temperate soft coral Alcyonium hibernicum broods parthenogenetic ova that are released as benthic planulae (Hartnoll, 1977). Other octocorals, particularly Alcyonacea, reproduce by vegetative fragmentation but few details are known. Studies of reproduction in the order Gorgonacea have described release of planula larvae following sexual fertilization (Goldberg and Hamilton, 1974; Weinberg and Weinberg, 1979).

The unbranched whip gorgonian Junceella fragilis Ridley is a common and conspicuous inhabitant of reefs along the Great Barrier Reef. J. fragilis colonies have a highly contagious distribution (Fig. 1) and this is shown herein to be the result of a newly discovered method of vegetative reproduction.

\section{DISTRIBUTION OF JUNCEELLA FRAGILIS}

The geographical distribution of Junceella fragilis has not been well studied. It was originally described from the Great Barrier Reef (Ridley, 1884) and specimens have since been reported from the Mergui Archipelago (Burma), Ceylon, the China Sea, the Philippines, the Persian gulf, Singapore (Ridley, 1888; Thomson and Henderson, 1905; Kükenthal, 1924; Toeplitz, 1929; Stiasny, 1940, 1951; Pax and Muller, 1956), and Okinawa (K. Muzik, pers. comm.). However, at least some of these are incorrectly identified specimens of $J$. juncea - a species widespread 


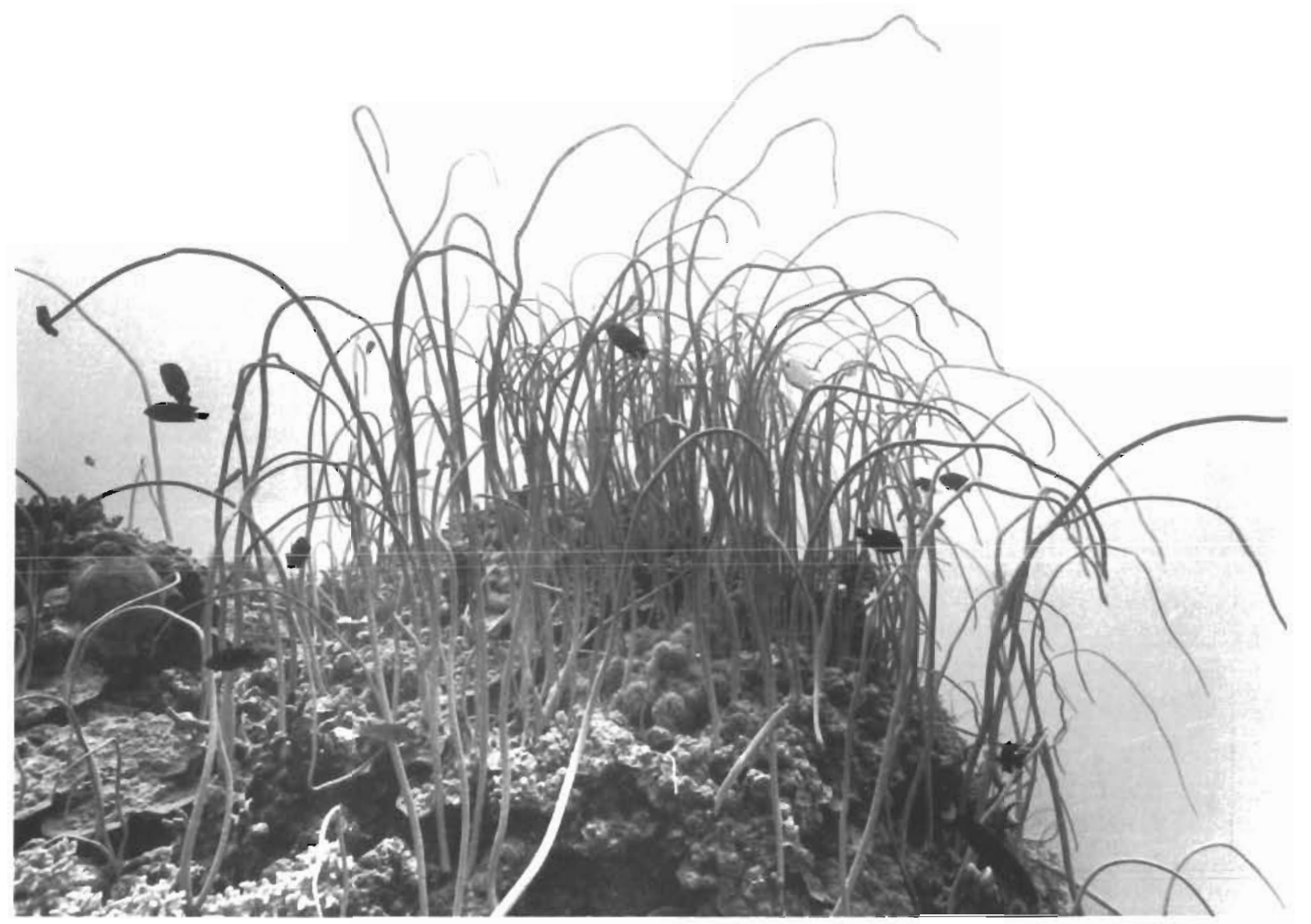

Fig. 1. Junceella fragilis. A dense clump at Lizard Island

throughout the Indo-West Pacific. In a review of the genus, Simpson (1901) re-examined the Mergui and Ceylon specimens identified as $J$. fragilis and considered them to be juveniles of $J$. juncea. He proposed that $J$. fragilis be synonymized with $J$. juncea as there were no stable differentiating characters. In Great Barrier Reef waters the 2 species occur side by side in the same habitats and are readily identified in situ by colouration and anatomical features. $J$. fragilis has a white, yellow or orange coenenchyme with brown zooxanthellae-containing polyps whereas J. juncea has darker orange, red or brown coenenchyme with white polyps.

\section{METHODS}

The tips of 26 Junceella fragilis colonies were photographed in situ on a weekly basis throughout September 1981 at a $7 \mathrm{~m}$ deep site at Bremner Point, Magnetic Island $\left(19^{\circ} 09^{\prime} \mathrm{S} 146^{\circ} 52^{\prime} \mathrm{E}\right)$. Underwater visibility ranged from approximately $4 \mathrm{~m}$ down to $20 \mathrm{~cm}$. At this same site, all $\mathrm{J}$. fragilis colonies in a densely populated $1 \mathrm{~m}^{2}$ quadrat were collected and measured for length. The direction of polyp orientation and presence of vegetative reproduction was also recorded. The fringing reef adjacent to Bremner Point (Geoffrey Bay) has been described by Bull (1982) and aspects of the oceanography of the area have been described by Walker (1981a, b) and Walker and O'Donnell (1981).

General observations on Junceella fragilis were made on 31 reefs between One Tree Island $\left(23^{\circ} 30^{\prime} \mathrm{S}\right.$ $\left.152^{\circ} 50^{\prime} \mathrm{E}\right)$ and Lizard Island (15 $\left.56^{\prime} \mathrm{S} 124^{\circ} 25^{\prime} \mathrm{E}\right)$ in the Great Barrier Reef. At Lizard Island the direction of polyp orientation and presence of vegetative reproduction was recorded from colonies at 3 separate sites: Granite Bluff, 103 colonies; North Point, 201 colonies; and McGillivray's Reef, 53 colonies.

Grafting experiments were attempted at Magnetic Island and Lizard Island by tying adjacent colonies together; however, the colonies reacted adversely to the presence of plastic or wire ties. Tissue necrosis occurred in the region of ties, preventing grafting from taking place (for this reason it was necessary to label the colonies under study at their bases). 


\section{RESULTS}

\section{Formation of daughter colonies}

Junceella fragilis reproduces vegetatively by a process of autotomy of terminal portions of a colony (Fig. 2). Prior to autotomy, polyps are uniformly distributed over the surface of the colony (Fig. 2a). The first sign of autotomy is the beginning of resorption of polyps over a 0.5 to $1 \mathrm{~cm}$ wide subterminal region of the colony (Fig. 2b). All polyps eventually disappear from the subterminal region (Fig. 2c) and the coenenchyme is resorbed in a transverse band until the daughter colony is connected to the parent colony only by the hair-like axial core (Fig. 2d). At this stage no living tissue connects the parent and daughter colonies: mechanical stimulation of the parent colony causes complete retraction of polyps of the parent colony but has no effect on the daughter colony and vice versa. The presence of the axial core restricts longitudinal growth to the apical region of the colony. Autotomy is not, therefore, a result of subterminal elongation or 'growing apart' of the parent and daughter colonies. The parent colony is unable to elongate until the daughter colony has broken away but the tip of the daughter colony continues to grow throughout the period of autotomy (Fig. 2). Final severance of the axial core and release of the daughter colony requires only gentle motion of the surrounding water. Daughter colonies drop rapidly to the seabed near the base of the parent although strong wave action or currents may carry them up to a metre or so horizontally as they sink. Following separation, both parent and daughter colonies regrow coenenchyme tissue over the small ends of exposed axial core. Regrowth is somehow prevented from occurring prior to separation since experimental removal of a ring of coenenchyme from other nonautotomizing regions of a colony was followed by rapid tissue regrowth and fusion over the exposed core. When epigrowth occurred on exposed axial core the colonies were capable of overgrowing or displacing it.

A variation on the order of autotomy events can occur if the axial core is broken by turbulent conditions or by the weight of the daughter colony prior to completion of tissue resorption. In this situation the broken ends tend to force their way outwards through the coenenchyme which maintains a covering of tissue over them (Fig. 3a).

Asexual reproduction of Junceella fragilis was first observed on fringing reef at Bay Rock $\left(19^{\circ} 07^{\prime} \mathrm{S}\right.$ $146^{\circ} 45^{\prime} \mathrm{E}$ ) in 1974 . Since then it has been observed at 31 reefs between One-Tree I. and Lizard I. At Bremner Point the status of the 26 monitored specimens after $31 \mathrm{~d}$ was as follows: $9(35 \%)$ had shown no sign of autotomy; $6(23 \%)$ had commenced and completed
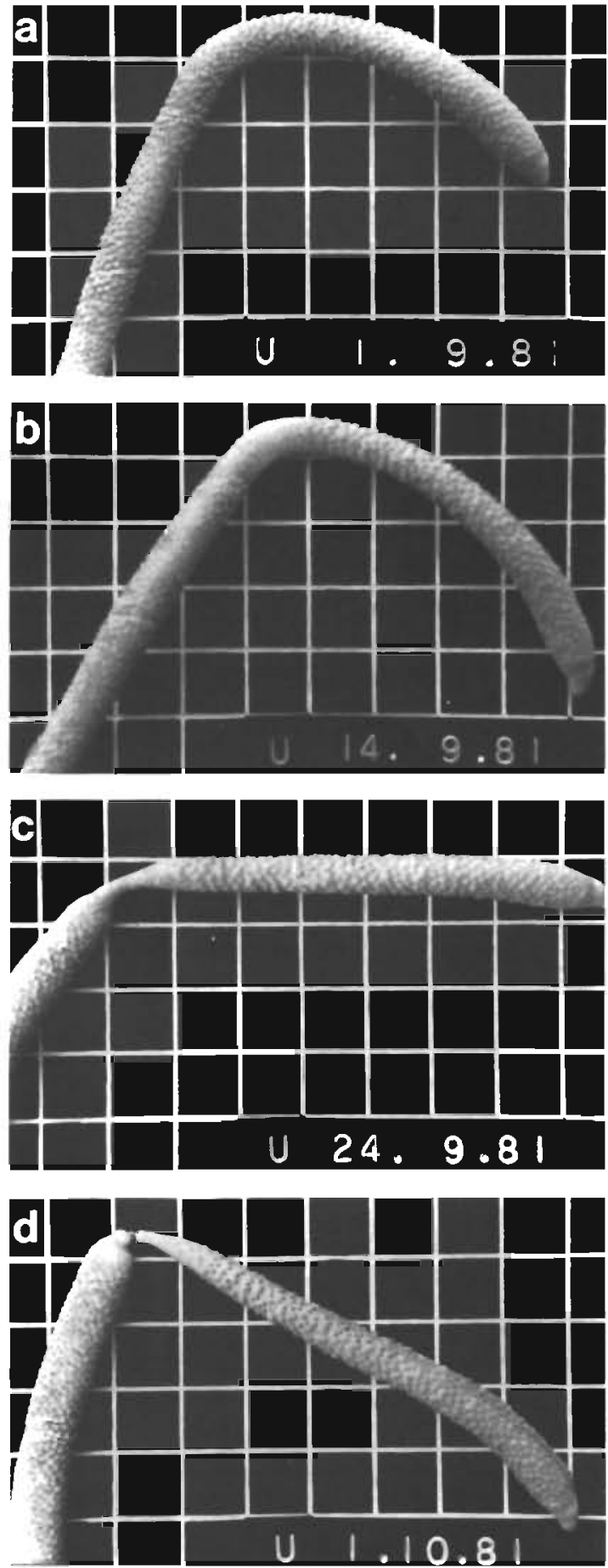

Fig. 2. Junceella fragilis. Daughter colony formation on a colony at Magnetic Island: (a) Day 1; (b) Day 14; (c) Day 24; (d) Day 31. Scale lines are $1 \mathrm{~cm}$ apart

autotomy; 4 (15\%) had commenced but not completed autotomy; $5(19 \%)$ that initially showed signs of autotomy had completed the process; and $2(8 \%)$ that initially showed signs of autotomy had not completed the process.

The metre quadrat from Bremner Point contained a 

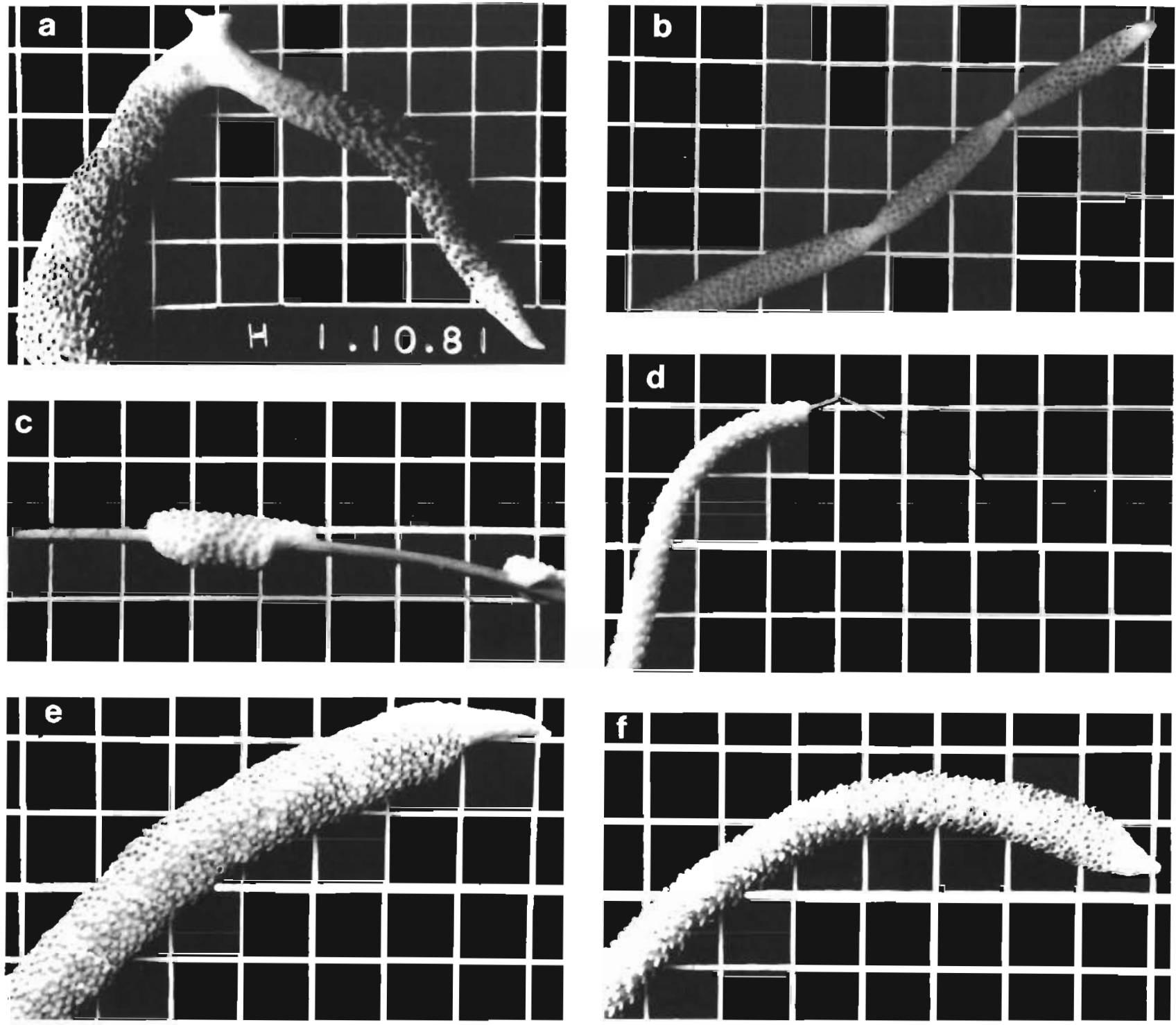

Fig. 3. Junceella fragilis. Colonies at Magnetic Island. (a) Colony with the axial core broken prior to completion of coenenchyme resorption; (b) twin daughter colonies in formation; (c) thick axial core exposed following predation on a colony (by fish?); (d) terminal hair-like axial core exposed following predation; (e) colony with downward-facing polyp verrucae; (f) colony with both upward-facing (upper surface) and downward-facing (lower surface) polyp verrucae

total of 325 individual Junceella fragilis colonies; 45 $(14 \%)$ of these were detached, free-lying daughter colonies and 55 of the 280 substrate-attached colonies $(20 \%)$ were in the process of forming daughter colonies. A similar overall proportion (18\%) of substrateattached colonies at Lizard Island had daughter colonies: the values at McGillivray's Reef and North Point being $26 \%$ and $16 \%$, respectively. The substrateattached colonies at Bremner Point ranged from 5 to $143 \mathrm{~cm}$ in length with a mean of $46.5 \mathrm{~cm}$ (s.e. $1.6 \mathrm{~cm}$ ), a median of $44 \mathrm{~cm}$, and a standard deviation of $26.3 \mathrm{~cm}$. The length frequency distribution is shown in Fig. $4 \mathrm{a}$. Mean lengths and standard deviations for parent- attached and detached daughter colonies were 8.0 $( \pm 3.4) \mathrm{cm}$ and $9.6( \pm 4.0) \mathrm{cm}$, respectively. The slightly greater lengths of the detached specimens (Fig. $4 \mathrm{~b}$ ) are due to continued growth of daughter colonies prior to (and possibly following) detachment. The maximum length recorded at Magnetic Island for a parent-attached daughter colony was $45 \mathrm{~cm}$. A J. fragilis colony normally produces 1 daughter colony at a time but up to 4 daughter colonies in series may occasionally be found on the same specimen. In the sample quadrat 5 specimens $(9 \%$ of the asexually reproducing colonies) had twin daughter colonies in formation (Fig. 3b). 

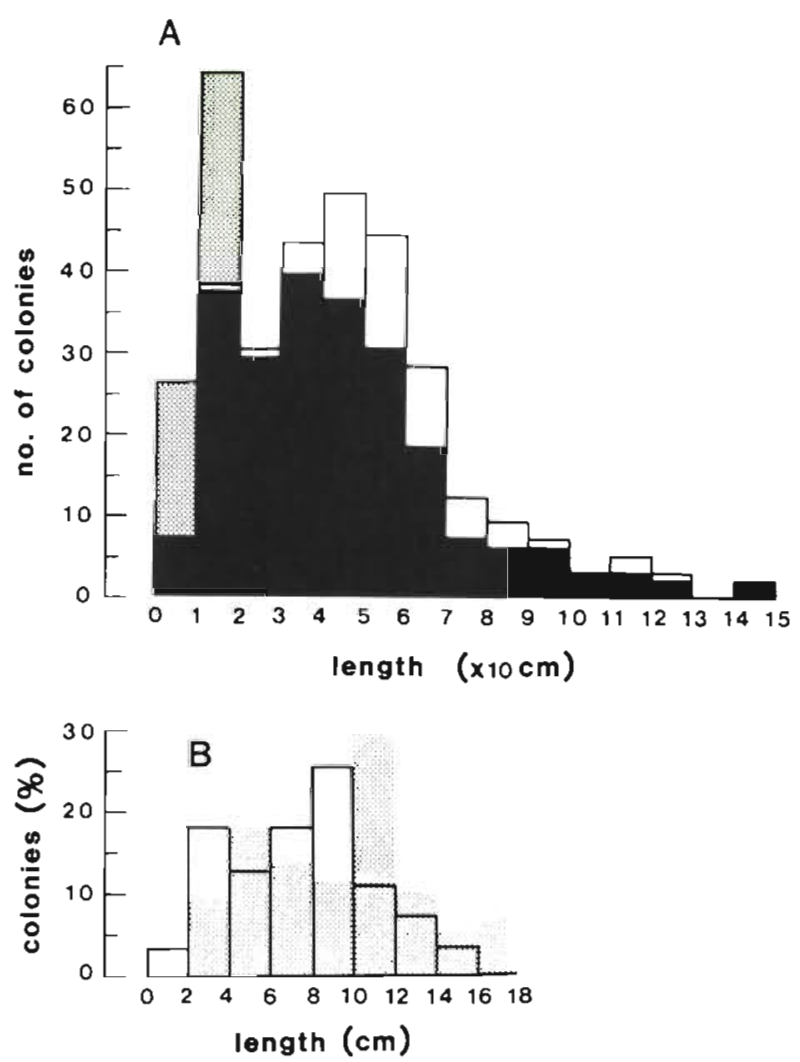

Fig. 4. Junceella fragilis. Length frequency distribution of colonies in a $1 \mathrm{~m}$ quadrat at Magnetic Island. (A) Total colonies including substrate-attached colonies without visible sign of autotomy (black), substrate-attached colonies with daughter colonies in formation (white), and detached, freelying daughter colonies (shaded); (B) comparison of \% length frequency of detached, free-lying daughter colonies (shaded) with parent-attached daughter colonies (solid line)

There is only a weak correlation between the length of a daughter colony and that of its parent colony (Pearson coefficient, $r=0.32, p<0.01$ ). This is largely due to the restriction of autotomy points to regions of new growth. The axial core in older regions of a colony becomes thickened (up to $9 \mathrm{~mm}$ ) and calcified so that, even if the coenenchyme is resorbed or removed (which may occur following attachment of an epibiont such as a crinoid), the core cannot be broken by water movements (Fig. 3c, d). This rigid section of axial core supports a relatively straight, upright colony but new regions of growth tend to bend under their own weight giving the upper colony a curved shape (Figs. 1 and 2). Although larger colonies do not necessarily produce larger daughter colonies, a strong correlation exists between colony length and the percentage of colonies with daughters (Fig. 5). This indicates that large colonies produce daughters more frequently than small colonies, at least until very old. The regression is linear for the first 9 length groupings $(p<0.001)$, however, analysis of variance of the regression shows curvature $(p<0.05)$ for all 10 groups. The very long colonies therefore have a significantly non-linear deviation from the trend and may produce proportionately fewer daughter colonies.

\section{Growth of daughter colonies}

Adult colonies normally occur with an upright habit directly from the holdfast, but the recently-detached daughter colonies lie on the bottom in a horizontal position. This means that colonies actively lift themselves to an upright position following or during holdfast formation. The lifting mechanism is probably one of differential regional expansion and contraction of the coenenchyme which is highly flexible. Either end of a daughter colony is capable of holdfast formation with the interesting consequence that the longitudinally appressed polyps and verrucae are often found facing towards the basal end of substrate-attached colonies (Fig. 3e). At McGillivray's Reef, North Point and Granite Bluff the proportions of substrate-attached colonies with downward-facing polyps were $24.5,10$ and $11.5 \%$, respectively (overall total $12.6 \%$ ). At Bremner Point only 1 quadrat colony $(0.4 \%)$ had downward-facing polyps although $15 \%$ of the photographed non-quadrat specimens were downward-facing. It is notable that the quadrat colonies were growing on a flat horizontal rock whereas colonies at the other sites were on irregular, heterogenous substrates. In the former case both ends of daughter colonies have a high probability of contact with suitable attachment

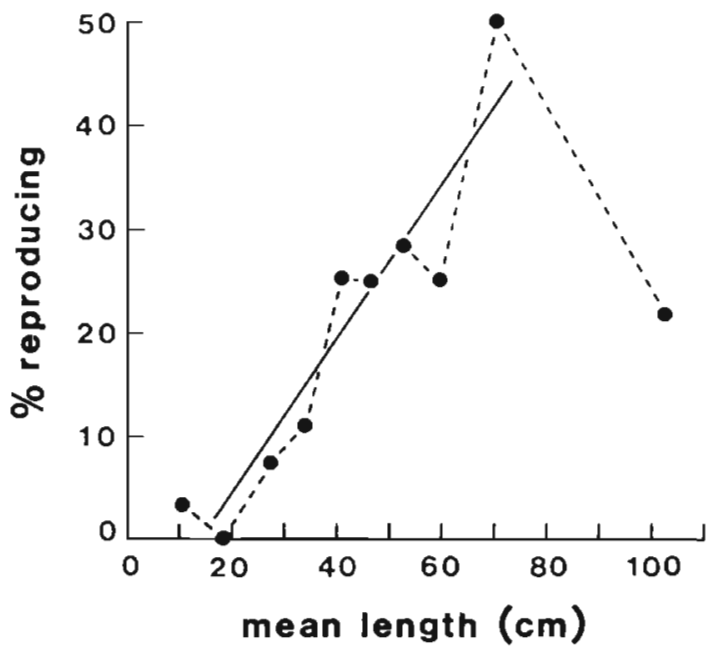

Fig. 5. Junceella fragilis. Relationship between frequency of daughter colony formation and colony length in a $1 \mathrm{~m}$ quadrat at Magnetic Island. The 280 substrate-attached colonies are divided into 10 groups of 28 by increasing length and the \% with daughter colonies in each group is plotted against length of the group. The regression for the first 9 points is $\mathrm{Y}=0.75 \mathrm{X}=10.8$ (solid line) 
sites and colonies may preferentially attach at the end that results in upward-facing polyps.

Alternatively, downward-facing colonies may have a higher mortality rate at some sites or may have some ability to reorient the direction of newly-formed polyps in the upward direction. The latter possibility is suggested by the presence of some colonies with longitudinal strips of both upward-facing and downward-facing polyps $(3.2 \%$ and $1.7 \%$ of the respective populations at Lizard Island and in the Bremner Point quadrat; Fig. 3f).

\section{DISCUSSION}

A number of species of Octocorallia reproduce vegetatively or by fragmentation though detailed descriptions of such processes are few. Cary (1919) remeasured colonies of the soft corals Lobophytum confertum and $L$. rigidum colonies in quadrats at Samoa after 15 mo and stated that it would appear most probable that the greater number of new individuals had arisen by the process of longitudinal division of some older colonies'. In the Red Sea, Fishelson (1973) found that following damage from tidal exposure to Lobophytum pauciflorum and Sinularia graye 'instead of one big colony, numerous smaller, but intact, colonies were formed'. Similar fragmentation reactions to adverse conditions have been suggested to occur in species of Sinularia, Lobophyton and Sarcophyton in New Guinea by Tursch and Tursch (1982). These authors have also described reproduction in Litophyton viridis and Nepthea erecta by a process akin to propagation by runners. In Great Barrier Reef waters, species of the soft coral genera Sinularia and Sarcophyton have a process of colony fission followed by active separation or 'movement' of sessile daughter colonies (B. Willis, pers. comm.). The xeniid soft coral Efflatounaria generates new colonies from runner-like branches which subsequently die (Z. Dinesen, pers. comm.) and a similar process occurs in the Caribbean gorgonian Briareum asbestinum (Kinzie, 1970; $\mathrm{H}$. Lasker, pers. comm.). Substrate attachment and growth of broken fragments is also important for population growth in a Caribbean Plexaura species (H. Lasker, pers. comm.).

A limited survey of gorgonian corals in Great Barrier Reef waters revealed no evidence of reproductive autotomy in other species. This is not surprising since, with the exception of Junceella juncea, all other gorgonian species increase their size in 2 or 3 dimensions and are not restricted to elongation on a single axis. A branching gorgonian releasing reproductive propagules that fall near its base would generate competition for branch space with daughter colonies attempting to grow up through the parent canopy. With a uniaxial animal there is no canopy and parental overtopping cannot occur. In the case of $J$. juncea, specimens longer than about $2 \mathrm{~m}$ are not found and it is likely that growth is determinate. The fact that very long $J$. fragilis colonies have relatively fewer daughters suggests that there is also some degree of determinate growth in this species despite its ability to avoid excessive elongation by detaching regions of new growth. Preliminary observations indicate that $J$. juncea has a lower growth rate than $J$. fragilis (the latter may increase in length by up to $1.4 \mathrm{~cm} /$ week) so autotomy may have evolved in necessary association with a high uniaxial growth rate.

Junceella juncea is wholly reliant on heterotrophy whereas $J$. fragilis captures plankton (Lewis, 1982) and also contains zooxanthellae. If competition for planktonic food occurs between individual colonies of a clump (Buss and Jackson, 1981), this presents a further disadvantage to vegetative reproduction and clump formation by the obligate heterotroph. Competition for plankton would be of lesser importance to J. fragilis if photosynthate is the major source of nutrition as has been shown for Heteroxenia fuscescens (Schlichter, 1982).

The widespread occurrence of dense, isolated clumps of Junceella fragilis (Fig. 1) demonstrates that autotomy is a relatively successful method of reproduction. This assumes that clumps are clones derived from one initial colony rather than amphimicts resulting from aggregated larval settlement (Gerrodette, 1981; Goreau et al., 1981; Scheltema et al., 1981; and others). Despite the failure of the experimental grafting technique the assumption is supported by observations of frequent natural grafts between $J$. fragilis colonies in the field. Previous work has shown that gorgonian tissues fuse with tissue taken from their own colony, but do not fuse with tissues from other colonies (Theodor, 1976; Adams, 1981).

It is widely considered that the major function of vegetative reproduction is to occupy fully a favourable local environment (Bell, 1981). Production of daughter colonies by the scleractinian corals Goniopora stokesi and the Fungiidae is furthermore an adaptation to colonization of soft substrates where settlement and survival of planulae are unlikely to be successful (Wells, 1966; Sheppard, 1981). The situation is different for $J$. fragilis daughter colonies which require a hard substrate for attachment and which may be seen in the field in varying states of decay where they have fallen onto sand. Despite such wastage of daughter colonies, $J$. fragilis demonstrates the effectiveness of non-dispersive, vegetative reproduction in a sessile, uniaxial (or sparsely branched) animal. Reproductive autotomy is ideally suited to fast growing species and 
it is anticipated that further examples of this phenomenon will be found in other marine organisms

\section{LITERATURE CITED}

Adams, R. O. (1981). Preliminary immunogenetics of Leptogorgia virgulata. Am. Zool. 21: 981

Bell, G. (1981). The masterpiece of nature: the evolution of genetics and sexuality. Croom Helm, London

Bull, G. D. (1982). Scleractinian coral communities of two inshore high island fringing reefs at Magnetic Island, north Queensland. Mar. Ecol. Prog. Ser. 7: 267-272

Buss, L. W., Jackson, J. B. (1981). Planktonic food availability and suspension-feeder abundance: evidence of in situ depletion. J. exp. mar. Biol. Ecol. 49: 151-161

Cary, L. W. (1931). Studies on the coral reefs of Tutuila, American Samoa with special reference to the Alcyonaria. Pap. Dep. mar. Biol. Carnegie Instn Wash. 27: 53-98

Fishelson, L. (1973). Ecological and biological phenomena influencing coral-species composition on the reef tables at Eilat (Gulf of Aquaba, Red Sea). Mar. Biol, 19: 183-196

Gerrodette, T. (1981). Dispersal of the solitary coral Balanophyllia elegans by demersal planular larvae. Ecology 62: 611-619

Goldberg, W. M., Hamilton, R. D. (1974). The sexual cycle in Plexaura homomalla. Stud. Trop. Oceanogr. 12: 58-61

Goreau, N. I., Goreau, T. J., Hayes, R. L. (1981). Settling, survivorship and spatial aggregation in planulae and juveniles of the coral Porites porites (Pallas). Bull. mar. Sci. 31: 424-435

Grassle, J. F. (1973). Variety in coral reef communities. In: Jones, O. A., Endean, R. (eds.) Biology and geology of coral reefs, Vol. 2, Biology, 1. Academic Press, London, p. $247-270$

Grigg, R. W. (1976). Fishery management of precious and stony corals in Hawaii. Sea Grant Tech. Rep. UNIHISEAGRANT-TR-77-03

Hartnoll, R. G. (1977). Reproductive strategy in two British species of Alcyonium. In: Keegan, B. F., Ceidigh, P. O., Boaden, P. J.S. (eds.) Biology of benthic organisms. Pergamon, New York, p. 321-328

Highsmith, R. C. (1982). Reproduction by fragmentation in corals. Mar. Ecol. Prog. Ser. 7: 207-226

Kinzie, R. A. (1970). The ecology of the gorgonians of Discovery Bay, Jamaica. Ph. D. thesis, Yale University, New Haven, Conn.

Kükenthal, W. (1924). Gorgonaria. Das Tierreich 47. De Gruyter, Berlin

Lewis, J. B. (1982). Feeding behaviour and feeding ecology of the Octocorallia (Coelenterata: Anthozoa). J. zool. Soc. Lond. 196: 371-384

Pax, F., Müller, L. (1956). Gli antozoi del museo civico di storia naturale di Trieste. Part 2: Gorgonaria. Atti Mus civ. Stor. nat. Trieste 20 (4): 133-162

Ridley, S. O. (1884). Alcyonaria. In: Report on the zoological collections made in the Indo-Pacific Ocean during the voyage of H. M. S. 'Alert' 1881-82. British Museum London, p. $327-365$

Ridley, S. O. (1888). Report of the alcyoniid and gorgoniid Alcyonaria of the Mergui Archipelago. J. Linn. Soc. 21: 242

Sammarco, P. W. (1982). Polyp bail-out: an escape response to environmental stress and a new means of reproduction in corals. Mar. Ecol. Prog. Ser. 10: 57-65

Scheer, G. (1959). Die Formenvielfalt der Riffkorallen. Bericht 1958/1959 Naturwissenschaftlicher Verein Darmstadt 50: 50-67

Scheltema, R. S., Williams, I. P., Shaw, M. A., Loudon, C. (1981). Gregarious settlement by the larvae of Hydroides dianthus (Pholychaeta: Serpulidae). Mar. Ecol. Prog. Ser. 5: $69-74$

Schlichter, D. (1982). Epidermal nutrition of the Alcyonarian Heteroxenia fuscescens (Ehrb.): absorption of dissolved organic material and lost endogenous photosynthates. Oecologia 53: 40-49

Sheppard, C. R. C. (1981). The reef and soft-substrate fauna of Chagos, Indian Ocean. J. nat. Hist. 15: 607-621

Simpson, J. J. (1910). A revision of the Gorgonellidae: 1. The juncellid group. Proc. R. Ir. Soc. (Sect. B) . 28: 247-376

Stiasny, G. (1940). Gorgonides et Alcyonides des collections du Museum National d'Histoire Naturelle (Première Partie). Archs Mus. natn. Hist. nat., Paris (6) 16: 109-145

Stiasny, G. (1951). Alcyonides et Gorgonides des collections du Museum National d'Histoire Naturelle. (II). Mem. Mus. Hist. nat., Paris (n.s.) A, Zool. 3 (1): 1-80

Theodor, J. L. (1976). Histo-incompatibility in a natural population of gorgonians. Zool. J. Linn. Soc. 58: 173-176

Thomson, J. A., Henderson, W. D. (1905). On the Alcyonaria. Report to the Govt. of Ceylon on the pearl oyster fisheries of the Gulf of Manaar. Vol. 3, Suppl. Rep. 20

Toeplitz, C. (1929). Die Gorgonarien Westindiens. Kap. 7. Die Familie Gorgonellidae, zugleich eine Revision. Zool. Jb. 16 (Suppl.): 235-376

Tursch, B. Tursch, A. (1982). The soft coral community on a sheltered reef quadrat at Laing Island (Papua New Guinea). Mar. Biol. 68: 321-332

Walker, T A. (1981a). Seasonal salinity variations in Cleveland Bay, northern Queensland. Aust. J. mar. Freshwat. Res. 32: 143-149

Walker, T. A. (1981b). Annual temperature cycle in Cleveland Bay, Great Barrier Reef province. Aust. J. mar. Freshwat. Res. 32: 987-991

Walker, T. A., O'Donnell, G. (1981). Observations on nitrate, phosphate and silicate in Cleveland Bay, northern Queensland. Aust. J. mar. Freshwat. Res. 32: 877-887

Weinberg, S., Weinberg, F. (1979). The life cycle of a gorgonian: Eunicella singularis (Esper, 1794). Bijdr. Dierk. 48 (2): $127-140$

Wells, J. W. (1966). Evolutionary development in the scleractinian family Fungiidae. In: Rees, W. J. (ed.) The cnidaria and their evolution. Academic Press, London, p. 223-246 